\title{
HUBUNGAN PERILAKU INTERPERSONAL GURU DAN PARTISIPASI PESERTA DIDIK DENGAN HASIL BELAJAR BIOLOGI DI SMA
}

\author{
Yusnia Eka Putri $^{1)}$, Supriyatin ${ }^{2 *}$, Eka Putri Azrai ${ }^{3)}$ \\ ${ }^{1,2,3)}$ Program Studi Pendidikan Biologi, FMIPA, Universitas Negeri Jakarta \\ *email: supriyatin@unj.ac.id
}

\section{Diterima 12 Maret 2018 disetujui 14 April 2018 diterbitkan 15 Mei 2020}

\begin{abstract}
Teacher's interpersonal behavior, play a critical role on teacher-student interaction. Teacher-student interaction related to student's participation on learining process. Student's participation related to student's outcome. The aim of this research is to investigate whether there is a correlation between teacher's interpersonal behavior ans student's participation with student outcome. The research was conducted at SMAN 2 Bekasi on October-November 2018. The total sample was 114 students of Mathematics and Science Programe at eleventh grade. The method used for this research is descriptive method. The result showed that there is a positive correlation between teacher's interpersonal behavior and student's biology outcome, a positive correlation between student's participation and student's biology outcome, a positive correlation between teacher's interpersonal behavior and student's participation, and also a positive correlation between teacher's interpersonal behavior and student's participation with student's biology outcome.
\end{abstract}

Keyword: learning outcome, participation, teacher's interpersonal behavior

\section{PENDAHULUAN}

Guru sebagai komunikator di kelas memiliki kontrol atas proses komunikasi dan kerjasama yang juga disebut sebagai perilaku interpersonal guru. Peserta didik akan mempersepsikan perilaku interpersonal guru dan membuat peta-peta perilaku interpersonal guru. Persepsi peserta didik tentang perilaku interpersonal guru tidak mudah berubah. Perbedaan persepsi peserta didik tentang perilaku interpersonal guru berkaitan dengan interaksi yang terjadi antara peserta didik dengan guru. Perbedaan pola interaksi salah satunya dapat dilihat dari partisipasi peserta didik dalam pembelajaran.

Perilaku interpersonal guru menjadi penting karena pola interaksi yang terbentuk akan membangun atmosfer kelas yang nyaman dan kondusif. Pola interaksi yang stabil dan positif menyebabkan partisipasi aktif peserta didik dalam pembelajaran. Partisipasi peserta didik memiliki keterkaitan dengan hasil belajar peserta didik. Semakin tinggi partisipasi peserta didik maka semakin tinggi hasil belajar peserta didik (Kvaschadze \& Zakareishvili, 2009).

Hasil belajar diartikan sebagai hasil dari proses interaksi peserta didik dengan lingkungan belajarnya selama proses belajar berlangsung yang menyebabkan perubahan perilaku, termasuk aspek kognitif, afektif, dan psikomotor yang digambarkan melalui simbol atau angka. Hasil belajar dipengaruhi oleh faktor internal dan eksternal. Faktor internal meliputi motivasi, bakat, minat, dan intelegensi. Faktor eksternal meliputi lingkungan belajar dan pembelajaran (Sholihah, Karyanto, \& Sugiharto, 2012). Minat peserta didik terhadap materi pembelajaran akan meningkatkan keterlibatan dan partisipasi peserta didik dalam pembelajaran (Cruickshank, Jenkins, \& Metcalf, 2012). Partisipasi peserta didik berhubungan dengan peningkatan hasil belajar, semakin tinggi partisipasi semakin tinggi skor akademik peserta didik (Kvaschadze \& Zakareishvili, 2009).

Perilaku orang-orang yang berinteraksi dipengaruhi oleh satu sama lain (Wubbels \& Levy, 2005). Ada dua dimensi yang dapat 
dilihat dalam perilaku manusia saat berinteraksi, yaitu dimensi dominan dan dimensi kasih. Dimensi dominan menggambarkan sikap dominansi, kekuatan, status, dan kontrol seseorang terhadap lainnya. Sedangkan dimensi kasih menggambarkan kasih sayang, persatuan, dan pertemanan (Pennings, Brekelmans, Sadler, Claessens, Want, \& Tartwijk, 2017). Perilaku interpersonal dibagi dalam dua dimensi, yaitu dimensi kasih disebut proximity (Coorperation-Opposition/ kerjasama-oposisi) dan dimensi dominansi yang disebut influence (DominanceSubmission/dominansi-submisi). Delapan skala perilaku interpersonal guru, yaitu kepemimpinan (leadership, DC/dominasikerjasama), penolong/ramah (helpful, CD/ kerjasama-dominasi), pengertian (understanding, $\quad \mathrm{CS} / \quad$ kerjasamapenaklukan), kebebasan peserta didik (student freedom, SC/penaklukankerjasama), ragu-ragu (uncertain, SO/penaklukan-oposisi), tidak puas (dissatisfied, OS/oposisi-penaklukan), mudah marah (admonishing, OD/oposisidominasi), dan tegas (strict, DO/dominasioposisi).

Partisipasi peserta didik merupakan keikutsertaan peserta didik atau keterlibatan peserta didik baik secara fisik dan emosional untuk mencapai tujuan pembelajaran sehingga peserta didik akan bertanggung jawab terhadap hasil belajarnya sendiri. Keikutsertaan peserta didik dapat dilihat dari kehadiran peserta didik di kelas, komentar atau tanggapan peserta didik terhadap pertanyaan-pertanyaan yang diberikan guru selama pembelajaran, pengerjaan tugas, dan kerjasama dalam kelompok (Kvaschadze \& Zakareishvili, 2009). Peserta didik yang terbiasa menyampaikan pendapat dan pertanyaan di kelas memiliki rasa percaya diri yang lebih tinggi. Hal ini juga mempengaruhi kemampuan komunikasi peserta didik. Partisipasi adalah faktor penting dalam kesuksesan akademik (Douglas \& Alemanne, 2007). Partisipasi peserta didik berhubungan erat dengan peningkatan pancapaian akademik.

Penelitian ini bertujuan untuk mengetahui hubungan perilaku interpersonal guru dan partisipasi peserta didik dengan hasil belajar Biologi peserta didik di SMA. Manfaat dari penelitian ini, sebagai pertimbangan bagi guru untuk menentukan strategi pembelajaran yang tepat agar peserta didik berpartisipasi aktif dalam pembelajaran. Selain itu juga sebagai wawasan baru bagi peneliti tentang perilaku interpersonal guru yang berkaitan dengan partisipasi peserta didik dan hasil belajar peserta didik.

\section{METODE}

Penelitian ini dilakukan di SMA Negeri 2 Bekasi. Penelitian dilakukan pada bulan Oktober-November tahun 2018. Sampel dari penelitian ini adalah peserta didik kelas 11 program MIPA. Pengambilan sampel dilakukan dengan teknik simple random sampling. Jumlah sampel adalah 114 orang yang ditentukan dengan rumus Slovin. Metode penelitian yang digunakan adalah metode deskriptif.

Variabel bebas dalam penelitian ini adalah perilaku interpersonal guru berdasarkan persepsi peserta didik $\left(\mathrm{X}_{1}\right)$ dan partisipasi peserta didik $\left(\mathrm{X}_{2}\right)$. Variabel terikat dalam penelitian ini adalah hasil belajar biologi peserta didik (Y). Data perilaku interpersonal guru berdasarkan persepsi siswa diambil dengan Questionnaire of Teacher Interaction (Wubbels \& Levy, 2005). Data partisipasi peserta didik diambil menggunakan kuesioner tentang partisipasi belajar peserta didik berdasarkan Finn (1991). Data hasil belajar peserta didik dilakukan dengan tes tertulis pada materi jaringan hewan. Tes tertulis berbentuk pilihan ganda yang berjumlah 55 butir soal.

Data penelitian yang didapatkan diuji normalitasnya dengan uji Kolmogorovsminov pada taraf signifikan 0,05. Kemudian dilanjutkan dengan uji homogenitas sampel dengan uji levene pada taraf signifikan 0,05. Pengujian hipotesis 
dilakukan dengan uji korelasi Kendall-tau dengan $\alpha=0,05$, dan juga uji korelasi Parsial Kendall-tau untuk menguji korelasi dua variabel bebas secara simultan dengan variabel terikat.

\section{HASIL DAN PEMBAHASAN}

Berdasarkan hasil penelitian yang diperoleh, skor persepsi peserta didik terhadap perilaku interpersonal guru yang terendah adalah 54 dan tertinggi adalah 96. Rata-rata skor persepsi peserta didik tentang perilaku interpersonal guru adalah 80,49. Frekuensi terendah skor perilaku interpersonal guru berada pada rentang batas kelas 93,5 - 98,5 yaitu sebanyak dua persen peserta didik. Frekuensi tertinggi skor perilaku interpersonal guru berada pada rentang batas kelas 78,5 - 83,5 yaitu sebanyak $26 \%$ peserta didik.

Instrumen perilaku interpersonal guru terdiri dari dua dimensi yang tersusun dari delapan skala. Berdasarkan hasil perhitungan skor dimensi perilaku interpersonal guru untuk dimensi pengaruh sebesar -0,09 dan dimensi kasih sebesar 0,27 . Skor dimensi dan persentase skala perilaku interpersonal guru dapat dilihat pada tabel 1 .

Tabel 1. Skor Dimensi Perilaku Interpersonal guru

\begin{tabular}{llllll}
\hline Dimensi & Skala & $\begin{array}{l}\text { Total } \\
\text { Skor }\end{array}$ & $\begin{array}{l}\text { Persen- } \\
\text { tase } \\
(\%)\end{array}$ & $\begin{array}{l}\text { Rata- } \\
\text { rata } \\
\text { Skor }\end{array}$ & $\begin{array}{l}\text { Skor } \\
\text { Dimensi }\end{array}$ \\
\hline Pengaruh & $\begin{array}{l}\text { Kepemim- } \\
\text { pinan }\end{array}$ & 2405 & 14.76 & 0.57 & -0.09 \\
& $\begin{array}{l}\text { Kebebasan } \\
\text { Siswa }\end{array}$ & 1216 & 7.47 & 0.28 & \\
& $\begin{array}{l}\text { Ragu-ragu } \\
\text { Tegas }\end{array}$ & 1883 & 11.56 & 0.44 & \\
& 650 & 3.99 & 0.15 & \\
\hline Kasih & Ramah & 2628 & 16.13 & 0.62 & 0.27 \\
& Pengertian & 2850 & 17.50 & 0.67 & \\
& Tidak Puas & 2691 & 16.52 & 0.63 & \\
& Mudah & 1966 & 12.07 & 0.46 & \\
\hline
\end{tabular}

Skor dimensi kasih yang lebih besar daripada skor dimensi pengaruh menunjukkan bahwa peserta didik menganggap guru lebih sering memperlihatkan perilaku ramah, pengertian, tidak puas, dan mudah marah. Persentase tertinggi pada skala yang menyusun dimensi kasih adalah persentase skala pengertian sebesar $17,50 \%$ dan yang terendah adalah skala mudah marah sebesar $12,07 \%$.

Persentase tertinggi pada skala yang menyusun dimensi pengaruh adalah persentase skala kepemimpinan, yaitu $14,76 \%$. Persentase skala terendah adalah persentase skala tegas, yaitu 3,99\%. Hal ini menunjukkan bahwa menurut peserta didik perilaku pada dimensi pengaruh yang paling sering muncul adalah kepemimpinan dan yang paling jarang adalah perilaku tegas.

Skor persepsi peserta didik tentang perilaku interpersonal guru digolongkan menjadi lima kriteria, yaitu sangat baik, baik, cukup baik, tidak baik, dan sangat tidak baik. Berdasarkan perhitungan skor persepsi peserta didik tentang perilaku interpersonal guru, skor tergolong dalam tiga kriteria, yaitu kriteria sangat baik berjumlah 41 orang (36\%), baik 63 orang (55\%), dan kriteria cukup baik 10 orang $(9 \%)$.

Berdasarkan hasil penelitian yang diperoleh, skor partisipasi peserta didik yang terendah adalah 54 dan tertinggi adalah 94. Rata-rata skor pertisipasi peserta didik adalah 74,74. Instrumen partisipasi peserta didik terdiri dari tiga skala. Hasil perhitungan menunjukkan bahwa skala yang memiliki persentase tertinggi adalah skala effort taking (berusaha) yaitu sebesar $40,62 \%$, sedangkan skala dengan persentase terendah adalah skala initiating taking (inisiatif) yaitu sebesar 28,49\%.

Tabel 2. Persentase Skala Partisipasi Peserta Didik

\begin{tabular}{lccc}
\hline \multicolumn{1}{c}{ Skala } & Skor & $\begin{array}{c}\text { Rata- } \\
\text { rata }\end{array}$ & Persentase \\
\hline $\begin{array}{l}\text { Effort taking } \\
\text { (Berusaha) }\end{array}$ & 4845 & 118.05 & $40.62 \%$ \\
$\begin{array}{l}\text { Initiating taking } \\
\text { (Inisiatif) }\end{array}$ & 3399 & 82.82 & $28.49 \%$ \\
$\begin{array}{l}\text { Non-participatory } \\
\text { (Tidak } \\
\text { Berpartsipasi) }\end{array}$ & 3685 & 89.79 & $30.89 \%$ \\
\hline \multicolumn{1}{c}{ Jumlah } & & 290.66 & $100 \%$ \\
\hline
\end{tabular}


Berdasarkan hasil penelitian yang diperoleh, nilai hasil belajar peserta didik pada materi jaringan hewan yang terendah adalah 43 dan tertinggi adalah 76 . Rata-rata nilai hasil belajar peserta didik pada materi jaringan hewan adalah 60,35. Nilai hasil belajar peserta didik digolongkan menjadi lima kriteria, yaitu sangat baik, baik, cukup, kurang baik, dan sangat kurang baik. Berdasarkan perhitungan yang dilakukan nilai hasil belajar peserta didik tergolong ke dalam dua kategori yaitu, kriteria baik berjumlah 66 orang (58\%) dan yang tergolong dalam kriteria cukup baik berjumlah 48 orang $(42 \%)$. Hasil perhitungan menunjukkan bahwa indikator yang memiliki persentase tertinggi adalah indikator menjelaskan struktur jaringan ikat yaitu sebesar $12,8 \%$, sedangkan indikator dengan persentase terendah adalah indikator menjelaskan sel punca, yaitu sebesar 4,3\%.

Berdasarkan pengujian hubungan perilaku interpersonal guru dengan hasil belajar peserta didik diperoleh nilai signifikansi (p) yang lebih kecil dari alpha $(\alpha)$, yaitu $0,007>0,05$ sehingga $\mathrm{H}_{0}$ ditolak yang berarti terdapat hubungan yang signifikan antara perilaku interpersonal guru dengan hasil belajar biologi. Koefisien korelasi $\left(\tau_{\mathrm{x} 1 \mathrm{y}}\right)$ sebesar 0,181 , hal ini menunjukkan bahwa tingkat hubungan antara perilaku interpersonal guru dan hasil belajar peserta didik sangat rendah.

Hasil pengujian hubungan partisipasi peserta didik dengan hasil belajar juga menunjukkan nilai signifikansi (p) yang lebih kecil dari alpha $(\alpha)$, yaitu $0,044>0,05$ sehingga $\mathrm{H}_{0}$ ditolak yang berarti terdapat hubungan yang signifikan antara partisipasi peserta didik dengan hasil belajar biologi. Koefisien korelasi $\left(\tau_{\mathrm{x} 1 \mathrm{y}}\right)$ sebesar 0,135 menunjukkan kekuatan hubungan antara partisipasi peserta didik dengan hasil belajar biologi sangat rendah.
Tabel 3. Persentase Indikator Hasil Belajar

\begin{tabular}{|c|c|c|c|c|}
\hline $\begin{array}{l}\text { Kompe- } \\
\text { tensi } \\
\text { Dasar }\end{array}$ & Indikator & Skor & Nilai & $\begin{array}{l}\text { Persentas } \\
\text { e }(\%)\end{array}$ \\
\hline \multirow{11}{*}{$\begin{array}{l}\quad 3.4 \\
\text { Mengana } \\
\text {-lis } \\
\text { keterkait- } \\
\text { an antara } \\
\text { struktur } \\
\text { sel pada } \\
\text { jaringan } \\
\text { hewan } \\
\text { dengan } \\
\text { fungsi } \\
\text { organ } \\
\text { pada } \\
\text { hewan }\end{array}$} & $\begin{array}{l}\text { Menganalisis } \\
\text { berbagai ben- } \\
\text { tuk dan struk- } \\
\text { tur sel } \\
\text { penyusun } \\
\text { jaringan epitel }\end{array}$ & 226 & 39.6 & 7.9 \\
\hline & $\begin{array}{l}\text { Mengidentifi- } \\
\text { kasi jaringan } \\
\text { epitel }\end{array}$ & 218 & 38.2 & 7.6 \\
\hline & $\begin{array}{l}\text { Menjelaskan } \\
\text { macam-macam } \\
\text { jaringan epitel }\end{array}$ & 285 & 50.0 & 9.9 \\
\hline & $\begin{array}{l}\text { Menjelaskan } \\
\text { struktur } \\
\text { jaringan ikat }\end{array}$ & 367 & 64.4 & 12.8 \\
\hline & $\begin{array}{l}\text { Mendeskripsi- } \\
\text { kan berbagai } \\
\text { macam jaring- } \\
\text { an ikat dan } \\
\text { fungsinya } \\
\text { dalam tubuh } \\
\text { hewan/manusia }\end{array}$ & 235 & 41.2 & 8.2 \\
\hline & $\begin{array}{l}\text { Mengidentifika } \\
\text { si jaringan ikat }\end{array}$ & 326 & 57.2 & 11.3 \\
\hline & $\begin{array}{l}\text { Menjelaskan } \\
\text { struktur dan } \\
\text { fungsi jaringan } \\
\text { otot }\end{array}$ & 280 & 49.1 & 9.7 \\
\hline & $\begin{array}{l}\text { Menjelaskan } \\
\text { macam-macam } \\
\text { jaringan otot }\end{array}$ & 295 & 51.8 & 10.2 \\
\hline & $\begin{array}{l}\text { Menjelaskan } \\
\text { struktur dan } \\
\text { fungsi jaringan } \\
\text { saraf }\end{array}$ & 189 & 41.4 & 8.2 \\
\hline & $\begin{array}{l}\text { Mengaitkan } \\
\text { struktur } \\
\text { jaringan dengan } \\
\text { letak dan } \\
\text { fungsinya } \\
\text { dalam tubuh } \\
\text { hewan/manusia }\end{array}$ & 287 & 50.4 & 10.0 \\
\hline & $\begin{array}{l}\text { Menjelaskan } \\
\text { Stem Cell/Sel } \\
\text { Punca }\end{array}$ & 123 & 21.6 & 4.3 \\
\hline Jumlah & & & 505.0 & 100 \\
\hline
\end{tabular}

Hasil pengujian hubungan perilaku interpersonal guru dengan partisipasi peserta didik, menunjukkan nilai signifikansi (p) yang lebih kecil dari alpha $(\alpha)$, yaitu $0,000>0,05$ sehingga $\mathrm{H}_{0}$ ditolak yang berarti terdapat hubungan yang signifikan antara partisipasi peserta didik dengan hasil belajar biologi. Koefisien korelasi $\left(\tau_{\mathrm{x} 1 \mathrm{y}}\right)$ sebesar 0,248 menunjukkan kekuatan hubungan antara perilaku 
interpersonal guru dan partisipasi peserta didik adalah rendah.

Pengujian hubungan perilaku interpersonal guru dan partsipasi peserta didik dengan hasil belajar dilakukan dengan uji korelasi parsial kendall. Berdasarkan hasil perhitungan uji parsial kendall diperoleh nilai koefisien korelasi parsial kendall sebesar 0,155 . Hal ini menunjukkan bahwa kekuatan korelasi sangat redah. Perhitungan nilai z dilakukan untuk melihat signifikansi. Berdasarkan hasil penelitian $\mathrm{z}$ hitung sebesar 2,445 dengan $\mathrm{z}$ tabel sebesar 1,9 hal ini menunjukkan nilai $\mathrm{z}$ hitung $>\mathrm{z}$ tabel yang artinya terdapat hubungan antara perilaku interpersonal guru dan hasil belajar peserta didik dengan mempertimbangkan partisipasi peserta didik.

Perilaku interpersonal guru penting dalam pembelajaran karena menjadi salah satu faktor untuk membangun iklim kelas yang kondusif. Iklim kelas yang kondusif mendukung peserta didik untuk belajar dengan maksimal dan meraih pencapaian hasil belajar yang tinggi. Perilaku interpersonal guru juga menentukan hubungan interpersonal antara guru dengan peserta didik. Hal ini sesuai dengan penelitian Zhu (2013), perilaku guru yang suportif dan kooperatif berpengaruh kepada performa peserta didik di kelas. Beberapa penelitian mengatakan perilaku guru yang cendrung lebih disukai peserta didik adalah kepemimpinan, ramah, dan pengertian.

Berdasarkan hasil perhitungan uji korelasi antara perilaku interpersonal guru dan hasil belajar peserta didik, diketahui bahwa terdapat hubungan positif. Hal ini sesuai dengan hasil penelitian Purba, Supriyatin, \& Sigit (2015), yang menyatakan bahwa terdapat hubungan positif antara persepsi peserta didik tentang perilaku interpersonal guru dengan hasil belajar biologi. Koefisien korelasi yang didapat sebesar 0,181 yang berarti terdapat korelasi positif dengan kriteria sangat rendah. Hal ini sesuai dengan hasil penelitian Witt, Wheeless, \& Allen (2004), yang menyatakan bahwa terdapat korelasi positif dengan tingkat asosiasi rendah dengan hasil belajar peserta didik. Semakin tinggi persepsi peserta didik tentang perilaku interpersonal guru maka semakin tinggi juga hasil belajar peserta didik. Kenaikan hasil belajar tidak tinggi karena keeratan hubungan sangat rendah.

Berdasarkan hasil penelitian terdapat skor perilaku interpersonal yang tinggi namun tidak menunjukkan hasil belajar yang tinggi. Sebanyak $11 \%$ dari peserta didik yang menilai perilaku guru tinggi namun memiliki hasil belajar rendah. Hal ini sesuai dengan penelitian Hagenauer, Hascher, \& Volet (2015), yang menyatakan bahwa kekuatan dari ikatan interpersonal antara guru dengan peserta didik di sekolah menengah lebih rendah dibandingkan dengan sekolah dasar. Meskipun demikian, perilaku interpersonal guru merupakan salah satu faktor penting dalam pembelajaran karena berkorelasi secara positif terhadap hasil belajar peserta didik. Tingkat korelasi antara perilaku interpersonal guru dengan hasil belajar peserta didik termasuk kedalam kriteria rendah. Hal ini terjadi karena banyak faktor yang mempengaruhi hasil belajar.

Pengujian korelasi antara partisipasi peserta didik dengan hasil belajar biologi peserta didik, menunjukkan adanya hubungan positif. Hal ini sesuai dengan penelitian Tatum, Schwartz, Schimmoeller, \& Perry (2013), yang menyatakan bahwa partisipasi peserta didik di kelas berkorelasi dengan proses belajar peserta didik dan hasil belajar. Koefisien korelasi yang didapat sebesar 0,135 yang berarti terdapat korelasi dengan kriteria sangat rendah. Hal in terlihat dari kriteria partisipasi baik tidak diikuti oleh tingginya persentase kriteria hasil belajar peserta didik yang baik. Hasil penelitian menunjukkan terdapat 37 $(32,4 \%)$ peserta didik dengan skor partisipasi yang tinggi namun nilai hasil belajarnya pada kriteria cukup. Hal ini dapat terjadi karena peserta didik dengan partisipasi tinggi tidak terlalu mempermasalahkan pendapat peserta didik lain tentang dirinya, performa di kelas, dan kemampuan intelektualnya secara keseluruhan. 
Kekuatan hubungan antara partisipasi peserta didik dan hasil belajar yang sangat rendah sesuai dengan penelitian Roorda, Koomen, Spilt, dan Oort (2011), yang menyatakan bahwa kekuatan hubungan partisipasi dan hasil belajar cendrung pada kekuatan rendah hingga sedang pada peserta didik di sekolah menengah. Partisipasi peserta didik merupakan salah satu faktor penting untuk pencapaian peserta didik karena dengan mengetahui tingkat partisipasi peserta didik guru dapat memberikan arahan yang lebih kepada peserta didik dengan partisipasi yang rendah (Douglas \& Alemanne, 2007). Peserta didik yang berpartisipasi aktif di kelas memiliki memori pelajaran yang lebih kuat sehingga akan berpengaruh positif terhadap hasil belajar. Meskipun demikian, banyak faktor lain yang mempengaruhi hasil belajar.

Faktor lain yang berhubungan positif dengan hasil belajar adalah motivasi peserta didik. Faktor motivasi berpengaruh secara signifikan terhadap hasil belajar peserta didik (Maulana, Opdenakker, den Brok, \& Bosker, 2012). Motivasi peserta didik yang tinggi akan menyebabkan kenaikan hasil belajar peserta didik. Kesungguhan peserta didik dalam pembelajaran juga memiliki hubungan yang positif terhadap hasil belajar (Miarsyah, Putrawan, \& Wulandari, 2016).

Hasil perhitungan uji korelasi antara perilaku interpersonal guru dan partisipasi peserta didik menunjukkan hubungan positif. Koefisien korelasi yang didapat sebesar 0,248 yang berarti terdapat korelasi positif dengan kriteria rendah. Adanya hubungan yang positif sesuai dengan hasil penelitian Hagenauer, Hascher, \& Volet (2015), yang menyatakan bahwa, hubungan interpersonal guru dan peserta didik yang positif akan meningkatkan partisipasi peserta didik dalam pembelajaran. Hubungan interpersonal yang positif terbentuk dari persepsi peserta didik tentang perilaku interpersonal guru tetapi juga dari persepsi guru terhadap perilaku peserta didik.

Hubungan interpersonal guru dan peserta didik dapat meningkatkan partisipasi peserta didik (Shernoff, et al., 2016). Hubungan interpersonal akan membentuk lingkungan belajar yang kondusif. Lingkungan pembelajaran mempengaruhi tingkat partisipasi peserta didik. Peserta didik yang merasa takut berpartisipasi di kelas menggap lingkungan kelasnya mengancam mereka. Takut mengalami kegagalan juga menjadi salah satu alasan peserta didik tidak ingin berpartisipasi (Frisby, Berger, Burchett, Herovic, \& Strawser, 2014). Peserta didik dengan tingkat partisipasi yang rendah juga terlalu takut dengan pendapat guru dan peserta didik lain ketika mereka melakukan kesalahan di depan kelas.

Selain itu, iklim kelas yang kondusif akan mempengaruhi motivasi peserta didik untuk ikut berpartisipasi aktif dalam pembelajaran. Hal ini sesuai dengan penelitian Sigit, Putrawan, \& Sulfitania (2016), yang menyatakan bahwa persepsi peserta didik yang positif tentang iklim kelas adalah ketika guru memotivasi, mengavaluasi, memberikan inspirasi, dan memberikan reward sehingga kondisi ini berdampak positif terhadap hasil belajar peserta didik. Umpan balik positif dari guru juga akan mempengaruhi kepercayaan diri peserta didik, sehingga saat kepercayaan peserta didik tinggi maka partisipasi peserta didik juga akan meningkat (Abdullah, Abu Bakar, \& Mahbob, 2012). Menurut penelitian Krohn, et al., (2010), peningkatan partisipasi peserta didik juga dipengaruhi oleh penguatan positif atau reward yang di dapatkan peserta didik.

Hasil perhitungan uji korelasi perilaku interpersonal guru dan partisipasi peserta didik dengan hasil belajar biologi peserta didik menunjukkan terdapat hubungan positif. Nilai z hitung yang lebih besar dari z tabel menunjukkan bahwa korelasi bersifat signifikan. Koefisien korelasi yang didapat sebesar 0,155 yang berarti terdapat korelasi positif dengan kriteria sangat rendah. Koefisien korelasi ini lebih kecil dibandingkan dengan koefisien korelasi antara perilaku interpersonal guru dengan hasil belajar peserta didik. 
Korelasi yang positif menunjukkan bahwa peningkatan skor persepsi peserta didik tentang perilaku interpersonal guru dan partisipasi peserta didik menyebabkan kenaikan hasil belajar. Persepsi peserta didik tentang periaku interpersonal guru mempengaruhi partisipasi peserta didik di kelas. Berdasarkan penelitian Paolini (2015), peserta didik yang menganggap guru peduli pada keberhasilan peserta didik akan membuat peserta didik merasa memiliki kesempatan untuk berhasil dan keinginan untuk terlibat dalam pembelajaran menjadi lebih besar. Keterlibatan peserta didik dalam pembelajaran berpengaruh positif terhadap hasil belajar peserta didik.

Keterlibatan peserta didik dalam pembelajaran tidak lepas dari peran guru. Salah satunya peran guru dalam menentukan strategi yang tepat supaya semua peserta didik berpartisipasi aktif dalam pembelajaran. Hal yang dapat dilakukan mungkin dengan membentuk kelompokkelompok belajar yang lebih kecil. Peserta didik kemungkinan akan lebih aktif dalam kelompok kecil dibandingkan kelompok besar. Semakin peserta didik aktif berpartisipasi akan semakin banyak hal yang dipelajari sehingga mempengaruhi hasil belajar peserta didik.

Tingkat korelasi yang sangat rendah menunjukkan bahwa ada faktor lain yang lebih berkorelasi dengan hasil belajar peserta didik. Hasil belajar peserta didik tidak hanya dipengaruhi oleh faktor dari guru tetapi juga dari diri peserta didik sendiri. Motivasi internal memiliki peran yang signifikan. Faktor internal lain yang berhubungan dengan hasil belajar adalah efikasi diri peserta didik dan penalaran ilmiah peserta didik (Sigiro, Sigit, \& Komala, 2017). Selain itu gaya belajar peserta didik juga berpengaruh kepada hasil belajar (Azrai, Ernawati, \& Sulistianingrum, 2017).

\section{SIMPULAN}

Berdasarkan hasil penelitian dapat disimpulkan bahwa:

1. Terdapat hubungan yang positif antara perilaku interpersonal guru dengan hasil belajar biologi peserta didik. Semakin tinggi nilai persepsi peserta didik tentang perilaku interpersonal guru berhubungan dengan kenaikan hasil belajar peserta didik.

2. Terdapat hubungan yang positif antara partisipasi peserta didik dengan hasil belajar biologi peserta didik.

3. Terdapat hubungan yang positif antara perilaku interpersonal guru dengan partisipasi peserta didik.

4. Terdapat hubungan yang positif antara perilaku interpersonal guru dan partisipasi peserta didik dengan hasil belajar peserta didik.

\section{DAFTAR PUSTAKA}

Abdullah, M. Y., Abu Bakar, N. R., \& Mahbob, M. H. (2012). Student's Participation in Classroom: What Motivates Them to Speak Up?. Social and Behavioral Sciences, 51, 516-522.

Azrai, E. P., Ernawati, \& Sulistianingrum, G. (2017). Pengaruh Gaya Belajar David Kolb (Diverger, Assimilator, Converger, Accommodator) terhadap Hasil Belajar Siswa pada Materi Pencemaran LIngkungan. Biosfer: Jurnal Pendidikan Biologi, 10, 9-16.

Cruickshank, D. R., Jenkins, D. B., \& Metcalf, K. K. (2012). The Act of Teaching. New York: Mc Graw Hill.

den Brok, P., Brekelmans, M., \& Wubbels, T. (2004). Interpersonal Teacher Behavior and Student Outcomes. School Effectiveness and School Improvement, 15 (3), 407- 442.

den Brok, P., Fisher, D., \& Koul, R. (2005). The Importance of Teacher Interpersonal Behavior for 
Secondary Science Students' Attitudes In Khasmir. Journal of Classroom Interaction, 40, 5-19.

Douglas, I., \& Alemanne, N. D. (2007). Measuring Student Participation and Effort. IADIS International

Conference on Cognition and Exploratory Learning in Digital Age (pp. 299-302). Tallahassee: CELDA.

Frisby, B. N., Berger, E., Burchett, M., Herovic, E., \& Strawser, M. G. (2014). Participation Apprehensive Students: The Influence of Face Support and Instructor-Student Rapport on Classroom Participation. Communication Education, 63 (2), 105-123.

Hagenauer, G., Hascher, T., \& Volet, S. E. (2015). Teacher Emotions in The Classroom: Associations with Students' Enggagement, Classroom Discipline and The Interpersonal Teacher-Student Relationship. European Journal of Psychology of Education, 30, 385-403.

Krohn, K. R., Aspiranti, K. B., Foster, L. N., McCleary, D. F., Taylor, C. M., Nalls, M. L., et al. (2010). Effects of Self-Recording and Contingent Credit on Balancing Participation Across Student. Journal of Behavior Education, 19 (2), 134155.

Kvaschadze, Z., \& Zakareishvili, M. (2009). Verbal Abuse by the Teacher and Student Classroom Participation, Academic Achievement, and Problem Behavior in Tbilisi Public School. Oslo: University of OsloNorway.

Maulana, R., Opdenakker, M. C. J. L, den Brok, P., \& Bosker, R. J. (2012). Teacher-Student Interpersonal Relationships in Indonesian Lower Secondary Education: Teacher and Student Perceptions. Learning Environment Research, 15, 251271.
Miarsyah, M., Putrawan, I. M., \& Wulandari, M. (2016). Hubungan antara Kesungguhan (Conscientiousness) dengan Hasil Belajar Biologi: Studi Korelasional terhadap Siswa Kelas X MIPA di SMA Negeri 38 Jakarta. Biosfer: Jurnal Pendidikan Biologi, 9 (1), 2833.

Paolini, A. (2015). Enhancing Teaching Effectiveness and Student Learning Outcomes. The Journal of Effective Teaching, 15 (1), 20-33.

Pennings, H. J., Brekelmans, M., Sadler, P., Claessens, L. C., Want, A. C., \& Tartwijk, J. V. (2017). Interpersonal Adaptation in Teacher-student Interaction. Learning and Instruction,55,41-57.

Purba, D. E., Supriyatin, \& Sigit, D. V. (2015). Hubungan antara Persepsi Siswa tentang Perilaku Interpersonal Guru dengan Hasil belajar Biologi Siswa. Biosfer: Jurnal Pendidikan Biologi, 8 (2), 14-19.

Roorda, D. L., Koomen, H. M., Spilt, J. L., \& Oort, F. J. (2011). The Influence of Affective Teacher-Student Relationships on Student's School Engagement and Achievement: A Meta-Analytic Approach. Review of Educational Research, 81 (4), 493529.

Shernoff, D. J., Kelly, S., Tonks, S. M., Anderson, B., Cavanagh, R. F., Sinha, S., et al. (2016). Student Engagement as A Function of Enviromental Complexity in High School Classrooms. Learning and Instruction, 43, 52-60.

Sholihah, I. M., Karyanto, P., \& Sugiharto, B. (2012). Kekuatan dan arah kemampuan metakognisi, kecerdasan verbal, dan kecerdasan interpersonal hubungannya dengan hasil belajar biologi siswa kelas XI IPA SMA Negeri 3 Sukoharjo. Pendidikan Biologi, 4 (1), 31-39. 
Sigiro, O. N., Sigit, D. V., \& Komala, R. (2017). Hubungan Efikasi Diri dan Penalaran Ilmiah dengan Hasil Belajar Biologi Siswa di SMA. Biosfer: Jurnal Pendidikan Biologi, 10 (2), 30-34.

Sigit, D. V., Putrawan, I. M., \& Sulfitania, C. (2016). Studi Komparatif Hasil Belajar Biologi Didasarkan pada Persepsi Siswa terhadap Iklim Kelas (Classroom Environtment Scale/CES): Studi Ex Post Facto pada Siswa di SMAN 1 Jakarta. Biosfer: Jurnal Pendidikan Biologi, 9 (2), 23-28.

Tatum, H. E., Schwartz, B. M., Schimmoeller, P. A., \& Perry, N. (2013). Classroom Participation and Student-Faculty Interactions: Does Gender Matter?. The Journal of Higher Education, 86 (6), 745-768.

Witt, P. L., Wheeless, L. R., \& Allen, M. (2004). A meta-analitical review of the relationship between teacher immediacy and student learning. Communication Monographs, 71 (2), 184-207.

Wubbels, T., \& Levy, J. (2005). Do You Know What You Look Like? Interpersonal Relationship in Education. London: The Falmer Press.

Zhu, C. (2013). Students' and Teachers' Thinking Style and Preferred Teacher Interpersonal Behavior. The Journal of Educational Research, 5 (106), 399-407. 